\title{
МЕТАТЕОРИЯ РУССКОГО МОДЕРНИЗМА: ОБЩЕСТВЕННАЯ СИТУАЦИЯ И ИСКУССТВО ХХ ВЕКА
}

\begin{abstract}
Аннотация. Русский модернизм ХХ в. - явление многоплановое. Традиционный подход кисследованию русского модернизма сформировал позицию, согласно которой модернизм - совершенно новое для российской общественной ситуации явление, пересмотревщее истоки и основы классического искусства и культуры и приведшее кпоявлению чуждой социокультурной реальности элементов. Но всежемодернизм не только характерен таким покушением на классику, он созидал новые культурные формы, которые могли бы на длительное время стать ликом отечественной культуры первой половины двадцатого столетия. Создавая свою метатеорию, модернизм апеллировал кпротиворечивой общественной ситуации в России начала ушедшего столетия, но при этом ставку делал на искусство, его различные виды. Таким образом, русский модернизм рассматривается в статье не только как философская система, но и метатеория, синтезирующая важнейшие качества культуры в ХХ в.
\end{abstract}

Ключевые слова: философия, модернизм, ценности, символы, культура, жизнь, творчество, искусство, форма, авангардизм.

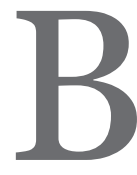

культуре русского модернизма XX в. выделялись ценностно-смысловые доминанты, не всегда совпадавшие с постулируемыми общественными идеалами. Многое из того, что возникало в художественных опытах модернизма, представляло собой эксперимент с действительностью и диктовало не всегда приемлемые условия для постижения жизненного пространства культуры. Однако эти программы культуротворчества, безусловно, имели социально ориентированный характер и выражали претензию на раскрытие сущностных свойств мира. К. Малевич, к примеру, в одной из своих деклараций отмечал, что люди, изображаемые художниками его времени, были хотя и в примитивных формах выражены, однако носили социальный план ${ }^{1}$. Эксперименты модернизма, зачастую поверхностные, мировоззренчески ошибочные, были далеки от жизнесозидательного выбора русской культуры, определявшегося не отказомот старьх культурньх форм, многие из которьх, действительно, становились анахронизмом реальности, и не выраженной направленностью кпоиску новой самобытной традиции и новой же культурной

\footnotetext{
${ }^{1}$ См. в книге: Гончарова Н.С., Ларионов М.Ф. Исследования и публикации. М., 2001. С. 204.
}

формы. В начале XX в. будущее русской культуры стояло за модернизмом думающим, духовным, обладающим не разрушительным характером, а виталистским, направленным на сохранениеживой и жизненной русской культуры смыслом. Эта особенность на протяжении столетия не изменялась: и в середине XX в., и в конце культурный эксперимент как технология придания культурному пространству дополнительных новаторских смыслов и дополнительного инновационного звучания был зависим от социальных действий и развития социальных отношений, с одной стороны. Однако, с другой стороны, философия модернизма оставалась на позициях аналитического проникновения в суть реальности и подчеркивала именно жизнецентрированный аспект освоения мира. Следует отметить, что для многих оценок достижений и неудач культурного двадцатого века оказался значимым именно ракурс модернистско-постмодернистского состояния реальности, в котором пребывает человек, социум и культура.

Философия модернизма и взгляды практиков новаторского художественного творчества встречали сопротивление тех, кто, как сами они полагали, мыслил о культуре более широко. Представитель русского символизма К. Бальмонт в лекции «Элементарные слова о символической поэзии» 
(1904) указывал на то, что сознание художниковмодернистов «не идет далее рамок земной жизни, определенных с точностью и с томящей скукой верстовых столбов» ${ }^{2}$. В декларации модерниста И.В. Игнатьева «Әго-футуризм» (1913) недвусмысленно характеризуются сами символисты: «Люди, превратившие искусство и жизнь в жратву, хлопочут вокруг пугающего их одра искусства» ${ }^{3}$. В отстаивании своих интересов модернисты применяли практику эпатажа, разрушения облика живого слова, изобретали заумный язык в отместку мистифицированному дискурсу символистов и их творческих попутчиков, которые мыслили себя истинными провидцами русской культуры.

Ницше в трактате «Происхождение трагедии из духа музыки» воплощает жизнестремительную стратегию, которая в культуре русского модернизма приобретает выраженные черты концептуального основания собственного философствования. В философии и творчестве модернизма ощущается именно то «неукротимое жадное стремление к жизни», которое, как считает Ницше, по сути, вырывает человека "на миг из вихря изменяющихся образов» ${ }^{4}$. Движение модернизма вперед было обусловлено прозрачной социально-философской программой, характерной для рубежа столетий: завоевать весь мир, стать всем в этом мире (так возникла идея «всёчества», получившая реализацию прежде всего в рамках культурно-художественной коммуникации русского модернизма). В этом смысле модернизм оказался включенным в социальный контекст эпохи. Поэтому в изучении спроса нового общества на новую культуру им был замечен ряд важнейших требований, которые предъявлялись к культуре будущего. Это во многом предопределило выбор виталистских стратегий в философии модернизма и в его культурно-художественных опытах. Как известно, власти, возводя политическую диктатуру, были всерьез обеспокоены стремлением многих культурных образований к диктатуре художественной. С другой стороны, новое общество пока еще было недостаточно сильно в вопросах обеспечения, контроля и поддержания всех основных функций общественной жизни. С. Матвеева замечает, что в условиях нового общества «население пытается замкнуться, не принимать на себя общесоциальные заботы, уменьшить

\footnotetext{
2 Литературные манифесты: От символизма до «Октября». M., 2001. C. 60.

3 Там же. С. 166.

${ }^{4}$ Ницше Фр. Рождение трагедии, или эллинство и пессимизм // Ницше Фр. Сочинения: в 2 т. Т. І. М., 1997. С. 121.
}

до минимума творческую энергию...» ${ }^{5}$. Концептуальная программа модернизма предусматривала замену художественной диктатуры социально-творческим демиургизмом, а также предлагала власти эффективные способы воздействия на народ. Так создавалась программная в культуре русского модернизма метатеория, которая в аспекте «всеединства» и системного культурного синтеза XX в. соединяла политику, эстетику, искусство и сознание активных народных масс. Кроме того, модернизм готов был стать вместилищем всенародной творческой энергии и тем самым освободить власти нового общества от принятия оторванных от жизни директив по вопросам культуры. В этом заключается важнейшая стратегия в культуре русского модернизма. Она бъланаправленанаизменение всенародного «стандарта мышиления», в котором принципы разрушающей тактики долгое время оставались ведущими и в котором постепенно происходило вытеснение накапливающейся социальной экспрессии концептуальными формами культурно-художественного освоения реального пространства.

Образ культурсозидающего коллектива «МЫ» становится еще одной когнитивной формой в процессе жизнестремительного движения русской культуры ХХ в. Этот образ все больше закреплялся за модернизмом, философски подходившим к вопросу о создании нового общества. Если в пространстве русской культуры основные культурсозидающие функции закреплялись за интеллигенцией, то модернизм также оказывался вовлеченным в эти процессы и последовательно реализовал задачи культуроцентричного сообщества. Таким образом, модернизм, создавая собственную концепцию личности, ориентировался и на задачи социокультурного плана, стоявшие перед властью и наиболее активными культурными движениями и направлениями на протяжении всего двадцатого столетия. Поэтому определение модернизма не только как исключительно культурно-художественного феномена, мировоззренческой парадигмы и эпохального стиля, но и как культуроцентричного сообщества, реализующего установки на построение новой культурной системы России, в полной мере позволяет судить о виталистской стратегии культуроцентризма, проявляющейся в философии модернизма и конкретных действиях его представителей.

\footnotetext{
5 Матвеева С. Расколотое общество: путь и судьба России // Ахиезер А.С. Россия: критика исторического опыта (Социокультурная динамика России). Т. І. Новосибирск, 1997. С. 13.
} 
Культуроцентричное сообщество «мы» становится полюсом жизненной энергии, поддерживающей и политику, и творчество, и новое общество, и новую культуру. Сторонник концепции пролетарской культуры Н.И. Бухарин коллективизм наделял механической силой - «рабочий класс, захватывая государственную власть, терпя нужду и лишения, в то же время, через культурную обработку своих сочленов, выработал кадры, которые позволят ему управлять твердой рукой всей страной» ${ }^{6}$. Один из представителей модернизма В. Кириллов добавлял к механической энергии «мы»-коллектива созидательное «горение гордых душ»: «Мы несметные, грозные легионы Труда. Мы победили пространства морей, океанов и суши, Светом искусственных солнц мы зажгли города. Пожаром восстаний горят наши гордые души» («Мы», 1917)7.

Выплески жизненной энергии представителей модернизма были всеохватными и распространялись как в социальных действиях, связанных, к примеру, с переоборудованием рабочих мест, так в интеллектуальной среде творчества, науки, философии. Примечательно, что на идеологической платформе футуризма даже была создана группа коммунистов-футуристов с аббревиатурой «комфут». Общая политическая программа этой группы совпадала с программой партии. Футуризм брал на себя трудные обязанности по расчистке художественных рядов и согласование художественных проектов с властью. К. Аймермахер приводит в связи с этим интересный факт о привязанности авангардистов к эпистолярному жанру: регулярно в Агитпроп ЦК партии поступали письма от деятелей модернистского толка с просьбами предоставить «академический паек» для угодных деятелей культуры. Ярлыками награждались в этих посланиях известные люди: Мандельштам - «поэт с мистикорелигиозным уклоном, и Республике никак не нужен», Шершеневич и Мариенгоф - «литературное кривлянье». В этом ряду Маяковский - «известный поэт, приемлющий революцию» и т.д. ${ }^{8}$

Важнейшая жизнеформирующая стратегия в культуре русского модернизма XX века, состоящая в поиске мировоззренческих и конкретно-материальных основ построения нового культурно-исторического пространства и модернистской сверхреальности, допускала использование различных

\footnotetext{
${ }^{6}$ Бухарин Н.И. Революция и культура. М., 1993. С. 52.

7 Аймермахер К. Политика и культура при Ленине и Сталине. М., 1998. С. 152.

8 Там же. C. 157-160.
}

эпатажных технологий. Безусловно, философия модернизма обозначала рубежи создания цельного нового мира, но преимущественно на базе неограниченных и тотальных художественных проектов, не всегда учитывавших особенности культурно-художественной коммуникации двадцатого столетия, достаточно вольно трансформирующей культурнособытийную эпику. Впервые власть нового общества начинает осознавать, что в своем безудержном стремлении властвовать над всем миром идеологофилософские программы модернизма допускают возможности своего активного и эффективного участия в создании пролетарской диктатуры. В этом смысле философия модернизма трудно переживает «период трех великих аффектов», обозначенный $\Phi$ p. Ницше по отношению к европейскому нигилизму. Впервые власть понимает, что модернизм является не тем ее партнером, который окажется способным справиться с поставленной задачей создания нового мира, новой социокультурной реальности. А. Гастев, очерчивая контуры новой культурно-исторической ситуации в России, открыто высказывает сомнение в том, что модернизм как идейно-художественная система способен выполнять задачи, предъявляемые новым обществом к новой культуре: «...художникам слова придется разрешить уже не такую задачу, какую поставили себе футуристы, а гораздо выше. Если футуризм выдвинул проблему «словотворчества», то пролетариат неизбежно ее тоже выдвинет, но самое слово он будет реформировать не грамматически, а он рискнет...на технизацию слова» ${ }^{9}$. Однако модернизм не меняет своих мировоззренческих приоритетов, определяя возможности своего научного, творческого и руководящего участия в построении социокультурной реальности. Виталистская направленность модернистской философии культуры всеохватна и на пространственном уровне распространяется как манифестация космического масштаба: «Все что было до Нас, Мы повеленно объявляем несуществующим. Мир начинается Нами и от Нас. Мир был трупностью, а теперь благодаря Нам становится психостью. Вы!.. Станьте на колени и принесите жертву Великому Психу!» (из манифеста психофутуризма $)^{10}$.

На фонежизнесозидательного проявления своей социокультурной стратегии модернизм по-прежнему оказывался в зоне «третьего аффекта» - разрушения (Ницше). С этого момента идейно-художественная

\footnotetext{
9 Литературные манифесты: От символизма до «Октября». M., 2001. C. 333.

10 Там же. С. 189.
} 
концепция освоения модернизмом действительности становится для власти антикультурной. Очерчивается фронт социального преодоления модернистских мистификаций, которые признаются фактами ошибочного непроверенного культуротворчества и приобретают характер не философем и концептов, свидетельствующих о культурсозидательной стратегии модернизма, а противоречивых слепков с нового мира. Г. Зиммель в известной работе «Философия денег» предрек судьбу подобного рода явлений: «жизнь в своей чистой непосредственности стремится воплотить себя в явлениях и, насколько это для нее вообще возможно, обнаруживает вследствие их несовершенства основной мотив - борьбу против всякой формы» ${ }^{11}$.

Перед новой культурой, по мысли А.А. Богданова, стояли две грандиозные задачи: «Первая - самостоятельное творчество: сознать себя и мир в стройных живых образах, организовать свои духовные силы в художественной форме. Вторая - получение наследства: овладеть сокровищами искусства, которые созданы прошлым, сделать своим все великое и прекрасное в них...» (из статьи «О художественном наследстве») $)^{12}$. Получалось, что модернизм не справился ни с одной задачей. Социокультурные новации модернизма оказались неприемлемыми для эпохи русской культуры начала XX в., однако его виталистские стратегии по-прежнему оставались актуальными, поскольку создавали перспективу народного реформирования культурного пространства на мировоззренческом уровне и культурной жизни в масштабе гармонизации отношений человека и социума.

Существует несколько причин, которые не позволили русскому модернизму стать диктатурой в культуре двадцатого века. Одну причину называет Л. Троцкий: модернизм, несмотря на отказ от художественных традиций прошлого, все же продолжает оставаться «во многом богемски-революционным ответвлением старого искусства...» ${ }^{13}$. Стремление к диктатуре в культурной жизни не согласовывалось с богемным стилем жизни многих представителей модернизма, который граничил с открытой эксцентрикой, всплесками сопротивления официальной идеологической программе. Деятели культуры не были политиками, но активно стремились стать

11 Цит. по книге: Ионин Л.Г. Георг Зиммель - социолог. М., 1981. C. 85 .

12 Богданов А.А. Вопросы социализма: Работы разных лет. М., 1990. С. 426.

13 Троцкий Л.Д. Литература и революция. М., 1991. С. 26. таковыми. Между тем организация нового общества требовала прежде всего искусства и культуры политической, при этом навыки художественного профессионализма отодвигались на второй план. Примечательно, что сами «модернисты», кроме того, признавались, что их ряды «расцвечивались иногда и цветами анархии» ${ }^{14}$. Богемный образ жизни заставлял власть сомневаться в социально значимой роли модернизма, претендующего на место новой культуры в XX в.

По той причине, что модернизм легко маневрировал в системе культурных ценностей, отказываясь от одних ценностей и признавая примат других, ему трудно было доверить строительство новой культуры. За новой культурой, согласно А.А. Богданову, закрепилась задача стать самым могущественным орудием «организации коллективных сил, в обществе классовом - сил классовых» ${ }^{15}$. Жизнеутверждающая позиция модернизма подкреплялась его обращениями «в народ». Действительно, «модернисты», стремясь воплотить в своей философии и главным образом в творчестве идейные концепты всенародной «общественной» культуры, избрали тактику эффектной площадной и сценической работы. Парадоксально, что этим настойчивым желанием модернизм, напротив, встречал сопротивление людей - никто не понимал и не спешил изображать безумные черные квадраты.

С этого времени модернизм переходит от конструктивизма как фундамента его жизнесозидательных стратегий к деконструктивизму - началось разрушение многого из того, что было им самим достигнуто, и главным образом его мировоззренческих стереотипов. После того как партийные власти увидели в известных лозунгах «сбросить Пушкина» и «сжечь Рафаэля» прямое подстрекательство к порче государственного имущества («...и Рафаэля, в частности, можно было при случае продать за большие деньги» ${ }^{16}$ ), модернизм ужесточает свои требования, проникая в сферу государственной философии и политической эстетики: «захват экономического базиса» (К. Малевич); «человек тоже двурукое государство» (В. Хлебников), «мы станем всем!» (В. Маяковский) и т.д. Сопротивление модернизма, прежде поставленное на теоретическую основу, постепенно перерастает в открытую борьбу на всех флангах - в качестве действенных средств собственной идеоло-

\footnotetext{
14 Литературные манифесты: От символизма до «Октября». M., 2001. C. 202.

15 Там же. С. 327.

16 Цит. по книге: Гройс Б. Утопия и обмен. М., 1993. С. 40.
} 
гии признаются замалевывание символов власти, музыкальная какофония, площадная брань и т.д. Но самое главное - модернизм продолжает создавать иллюзию жизненной и эстетической гармонии, что было сопряжено с определенными мировоззренческими трудностями. Модернизм доказывал, что эйфория по художественной диктатуре, возникшая на фоне особого эмоционально-экспрессивного напряжения в XX в., - это нормальное желание, свидетельствующее об идеологической, социальной и культурно-художественной зрелости модернистского опыта. Модернизм может, имея твердую идеологическую платформу, изменить внешние формы поведения, стать той культурой труда, «производственничества», которая необходима новому обществу.

В той системе ценностно-смысловых координат, которая определяла ракурс противоречивого развития культурно-исторической эпохи в плане социального преображения российской действительности, а также в направлениях разрушения традиций и архетипов, созидания новых культурных форм и построения новых культурно-коммуникативных отношений, именно модернизм определял одну из важнейших социокультурных тенденций двадцатого века - концептуализацию жизнесозидательного начала русской культуры в сохранении ее духовных констант и целостности ее жизненного пространства.

Действительно, со временем меняется сама форма отношений модернизма к реальности: из искушенного новизной явления русской культуры он становится «товариществом», способным к открытому идейному диалогу и признанию социально-политической доктрины государства. Но все относительно: этот шаблон поведения усиливает звучание модернистского панэстетизма, определяющего идейно-художественные границы сплошной театрализации действительности. Модернизм здесь следует несколькими путями. Первый - отказ от релятивистской концепции построения нового мира, которая прежде всего вызывала настороженность власти. Именно в этом направлении модернизм проделал значительную работу: оптимистическая жизненная энергия проявлялась практически во всех художественных актах «модернистов», которые по возможности должны были исключать символику «деконструктивизма», «сдвигологии» и зауми. «Мы бросаем вызов телоглупости мира, зачиная новоебытие», - звучит в одном из манифестов психофутуриз- ма $^{17}$. «Новое бытие» следовало новым принципам. Оно, по мысли Б. Гройса, «развивалось от черного квадрата Малевича как символа абсолютного ничто и абсолютного отрицания мира» ${ }^{18}$ до форм культуры, стирающих эстетические границы красоты и безобразия ${ }^{19}$ и актуализирующих принципыжизнесозидательного начала в пространстве русской культуры. Особенно это проявилось в условиях постепенной мировоззренческой перестройки вектора виталистскихстратегиймодернизма, когда произошла поляризация социокультурных отношений на идеологическом уровне - «своя»-«чужая» культура, на художественном уровне - неоромантическаясоцреалистическая традиции, на философском социальное пространство-культурное пространство, а также «сдвигология»-жизнетворчество. Следует заметить, что опыт «модернистов» в этом направлении изначально носил преимущественно идейно-художественный характер и, действительно, был «формальным»: создавались различные формы, раздвигающие границы реальности и сверхреальности. Например, прием маски становится основным на пограничной территории красоты и безобразия. На смену модернистскому демиургизму приходит «выдержанная» рефлексия «комедии масок». Черный квадрат становится «живым, царственным младенцем»; каждый участник творческого процесса получал свою строго предписанную ему одному роль в соответствии с программой тотальной эстетизации мира. Это было открытое убеждение в своей правоте: в марте 1918 года из окон дома на углу Кузнецкого моста и Неглинного проезда в Москве были вывешены три картины Давида Бурлюка. Вне обстановки выставочного зала это был жест публичного осмеяния художественного творчества. В условиях неоднозначных оценок творческого направления модернизма этот акт являлся протестным и вне сомнения политическим.

Другой путь модернизма в театрализации действительности был связан с отказом от сущностного: стратегия художественного освоения

\footnotetext{
17 Литературные манифесты: От символизма до «Октября». М., 2001. С. 190.

18 Гройс Б. Рождение социалистического реализма из духа русского авангарда // Вопросы литературы. 1992. Вып. І. С. 51.

19 Сходный с этим замечанием мотив мы можем обнаружить у Г. Зиммеля, полагающего, что «современное» искусство «безразлично к понятию красоты и безобразия, связанных с проявлением форм, так же как и жизнь определяется не целью, а потоком сил, движущихся по ту сторону красоты и безобразия» (см.: Ионин Л.Г. Георг Зиммель - социолог. М., 1981. С. 120).
} 
пространства во многом формировалась на фоне «бессистемных ценностей», среди которых генеральной ценностью оставался духовный мир носителя культуры, но обыгрывался его натурализм, ипохондрия, усталость от жизни. Если поначалу душа для «модернистов» являлась символом времени и знаком вечности, то позже, в ситуации изменения программных установок в философии модернизма, появляются такие концепты, которые свидетельствуют об эволюции модернизма в иной системе ценностно-смысловых координат культуры и социума. Так, например, феномен «тускломедная Вседурь ${ }^{20}$ соотносится с традиционными ценностями духа, национального чувства. А в манифесте «Конечного Века Поези» обозначилась пессимистическая линия в культуре русского модернизма: «Человечество у мертвой точки: наивно опознанное самоцелью, оно не более, как ток разума к совершеннейшим формам» ${ }^{21}$.

Философская рефлексия модернизма в условиях смены многих принципиальных пунктов идеологической и эстетической программ XX века также претерпевает существенные метаморфозы. Прежде всего изменение коснулось внутреннего единства «товарищества» «модернистов». Открытое насаждение ницшеанской «воли к бытию», ставшее концептуальным положением двадцатого столетия, приобретало характер диктата, что достаточно серьезно нарушало привычный деловой ритм художественной деятельности представителей русского модернизма. Становится заметной деформация аксиологической системы культурного пространства модернизма, которое предельно сужается. В художественном мире, с одной стороны, по-прежнему сохраняется тенденция панэстетизма, определяющая эстетический ракурс освоения мира, с другой стороны, модернистская стратегия вырабатывает те идейно-художественные принципы, которые в ситуации ценностно-смысловой нестабильности XX века должны стать точкой отсчета новой живой культуры. Для модернизма такой культурой является востребованная обществом система художественно-аналитического постижения окружающей реальности через призму идеологии революционаризма и пролетариата в начале XX века и по принципу конфронтации официально установленным государством ценностям и нормам - в течение всего столетия.

\footnotetext{
${ }^{20}$ Цит. по книге: Ронен О. Серебряный век как умысел и вымысел. М., 2000. С. 112.

${ }^{21}$ Там же.
}

Однако как культуроцентричное сообщество, несущее определенную нравственную и мировоззренческую ответственность за сохранение духовного облика национальной культуры, «модернисты» ориентировались не только на доминировавший социальный дискурс культурной жизни, но и учитывали закономерности социокультурной динамики, определившей выделение жизнесозидательного начала в культурном бытии в качестве приоритетного. Поэтому в культуре русского модернизма постепенно, но достаточно интенсивно обозначался вектор перехода из состояния дионисийского опьянения с доминирующими концептами «сдвигологии» и «зауми» к аполлоническому озарению. Попытки «модернистов» преодолеть традиционную художественно-эстетическую оппозиционность «прекрасное»/ «безобразное» на фоне сложнейшей социокультурной ситуации уходили на второстепенный план и корректировались более сложным противостоянием культуры и жизни.

Культуроцентричное сообщество представителей модернизма во многом организуется по принципу демиургизма, который с точки зрения виталистской стратегии становится решающим приемом кипения жизненной энергии и проникновения во все сферы жизнедеятельности людей. Несмотря на неоднозначную оценку модернистских форм участия в культурной и социальной жизни России, среди которых всегда доминировало разрушительное начало и космополитичный нигилизм, все же феномен модернизма - это явление $\kappa y \wedge$ bту р о с б е р е а а ю щ е е, поскольку именно модернизм удлинил дистанцию между культурными формами, обращенными кчеловеку, развившимися как отклик на русский архаичный традиционализм, и разрушающцм пафосом и сокрушающими тенденциями социалистической культуры XX в., еще более отдалившей наступление эпохи человечной духовности. За нарочито эпатирующими художественными экспериментами «модернистов», находившихся в ситуации сложных мировоззренческих исканий своего времени и своего реципиента, скрывалось глубинное проникновение в образы новой действительности, неизбежно проявляющейся с наступлением двадцатого столетия. И в этом смысле именно шокирующий модернизм оказался способным увидеть и подчеркнуть духовный тупик русской культуры и человека в ней в начале новой культурно-исторической эры. После этого логично началось застывание всех созданных русским модернизмом культурных форм. Если говорить словом пророка своей эпохи Ницше, 
модернизм в условиях жесткого разделения сфер культурной и социальной жизни в российской действительности, следуя идейному закону «сильнейшего» - партии, постепенно превращался в «культуру, не имеющую никакого твердого, священного, коренного устоя, но осужденную на то, чтобы истощать всяческие возможности и скудно питаться всеми культурами» ${ }^{22}$. Такой ракурс движения русской культуры нельзя назвать в полной мере жизнеорганизующим, поскольку и жизненное пространство культурно-органической системы смыкалось на полюсах приятия или неприятия социальной действительности, маркерами которой оставались деструктивность и распространение повсеместно принципов пролетарской культуры, ориентированной на социалистические идеалы своего времени. Позиция модернизма как проводника совершенно иных культуротворческих принципов оказалась амбивалентной: с одной стороны, происходило вытеснение мировоззренческой доктрины модернизма идеологией пролетарской культурной системы, но с другой стороны, происходило дальнейшее развитие модернистской культуры России в парадигматике гармоничного и духовноориентированного созидания реальности. И в этом смысле модернизм, остававшийся верным своим принципам компенсации культурной архаики и преодоления инертности в пространстве русской культуры, был, пожалуй, единственной культурсозидающей силой.

\section{Список литературъ:}

1. Аймермахер К. Политика и культура при Ленине и Сталине. М., 1998. 208 с.

2. Богданов А.А. Вопросы социализма: Работы разных лет. М., 1990. 479 с.

3. Бухарин Н.И. Революция и культура. М., 1993. 350 с.

4. Гончарова Н.С., Ларионов М.Ф. Исследования и публикации. М., 2001. 252 с.

5. Гройс Б. Рождение социалистического реализма из духа русского авангарда // Вопросы литературы. 1992. Вып. І. С. 42-61.

6. Гройс Б. Утопия и обмен. М., 1993. 374 с.

7. Литературные манифесты: От символизма до «Октября». М., 2001. 384 с.

8. Матвеева С. Расколотое общество: путь и судьба России // Ахиезер А.С. Россия: критика исторического опыта (Социокультурная динамика России). Том I. Новосибирск, 1997. С. 3-41.

9. Ницше Фр. Рождение трагедии, или эллинство и пессимизм // Ницше Фр. Сочинения: в 2 т. Т. I. М., 1997. C. 48-157.

10. Ронен О. Серебряный век как умысел и вымысел. М., 2000. 152 с.

11. Троцкий Л.Д. Литература и революция. М., 1991. 400 с.

\section{References (transliteration):}

1. Aymermakher K. Politika i kul'tura pri Lenine i Staline. M., 1998. 208 s.

2. Bogdanov A.A. Voprosy sotsializma: Raboty raznykh let. M., 1990. 479 s.

3. Bukharin N.I. Revolyutsiya i kul'tura. M., 1993. 350 s.

4. Goncharova N.S., Larionov M.F. Issledovaniya i publikatsii. M., 2001. 252 s.

5. Groys B. Rozhdenie sotsialisticheskogo realizma iz dukha russkogo avangarda // Voprosy literatury. 1992. Vyp. I. S. 42-61.

6. Groys B. Utopiya i obmen. M., 1993. 374 s.

7. Literaturnye manifesty: Ot simvolizma do «Oktyabrya». M., 2001. $384 \mathrm{s.}$

8. Matveeva S. Raskolotoe obshchestvo: put' i sud'ba Rossii // Akhiezer A.S. Rossiya: kritika istoricheskogo opyta (Sotsiokul'turnaya dinamika Rossii). Tom I. Novosibirsk, 1997. S. 3-41.

9. Nitsshe Fr. Rozhdenie tragedii, ili ellinstvo i pessimizm // Nitsshe Fr. Sochineniya: V 2-kh tomakh. Tom I. M., 1997. S. 48-157.

10. Ronen O. Serebryanyy vek kak umysel i vymysel. M., 2000. $152 \mathrm{s.}$

11. Trotskiy L.D. Literatura i revolyutsiya. M., 1991. 400 s.

${ }^{22}$ Ницше Фр. Рождение трагедии, или эллинство и пессимизм // Ницше Фр. Соч.: в 2 т. Т. І. М., 1997. С. 149. 